\title{
NOTE
}

\section{Effect of organic solvents, temperature and EDTA on activity and stability of halophilic $\alpha$-amylase from Haloarcula sp. S-1}

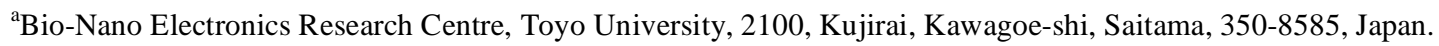 \\ ${ }^{\mathrm{b}}$ Department of Applied Chemistry, Faculty of Engineering, Toyo University, 2100, Kujirai, Kawagoe-shi, Saitama, 350-8585, \\ Japan.
}

Corresponding author: Tadamasa Fukushima, bioengtf@eng.toyo.ac.jp

Phone: +81-492-39-1390. Fax: +81-492-31-1031.

Received: September 9, 2005 / Revised: September 28, 2005 / Accepted: September 29, 2005

\begin{abstract}
More than $80 \%$ of residual halophilic $\alpha$-amylase (crude and purified) activity from strain S-1 was observed in the presence of various organic solvents. More than $78 \%$ remaining activity was detected after incubation for $120 \mathrm{hr}$ in the presence of styrene, toluene, benzene or chloroform. Enzyme activity and stability with chloroform were higher than that without chloroform at the low or high temperature, and enzyme activity was higher in the presence of chloroform than one without chloroform when EDTA (5-15 mM) was added.
\end{abstract}

Key words: halophilic $\alpha$-amylase, organic solvent, stability and products ratio

Starch-degrading enzymes, such as amylases, comprise various kinds of enzymes implicated in the hydrolysis of starch, and these are widely used in industrial processes 6,10 ). Moreover, amylase has become one of the most valuable enzymes in biotechnology, especially in the food- and starch-processing industries ${ }^{16)}$.

In halophilic archaea, amylase from Natronococcus amylolyticus was purified for the first time ${ }^{7,9)}$ and the gene was cloned ${ }^{8)}$. Also, amylase from Haloferax mediterranei was purified ${ }^{12,13)}$. Usually, halophilic enzymes are able to deal with high ionic strength in their environment and also need high ionic strength to maintain their function and structure ${ }^{2)}$ These enzymes function under extremely high salt concentrations, and they are stable under dry condition. In this context, archaea provide us with a ready source of proteins that may serve as model proteins that exist in high-salt concentrations and dry environment ${ }^{1,11)}$.
Recently, we reported about purification and characterization of halophilic $\alpha$-amylase from the new isolates Haloarchaeon, Haloarcula sp. strain S-1 and about organic solvent tolerance of the enzyme for the first time ${ }^{3)}$. Molecular mass of this enzyme was estimated to be $70 \mathrm{kDa}$ by sodium dodecyl sulfate-polyacrylamide gel electrophoresis. This amylase exhibited maximal activity at $50{ }^{\circ} \mathrm{C}$ in buffer containing $4.3 \mathrm{M} \mathrm{NaCl}, \mathrm{pH}$ 7.0. Moreover, this enzyme was active and stable in the presence of various organic solvents (toluene, benzene and chloroform etc.). Organic solvent tolerant amylase should be useful enzyme in industrial application. In this study, we report about effect of organic solvent on halophilic $\alpha$-amylase activity from Haloarcula sp. S-1 at various conditions.

First, purification of $\alpha$-amylase from Haloarcula sp. S-1 was performed. Purification methods were described elsewhere ${ }^{3)}$. Amylase activity was routinely assayed by the iodine-binding assay in $50 \mathrm{mM}$ tris- $\mathrm{HCl}$ buffer containing $0.2 \%$ starch and $4.3 \mathrm{M} \mathrm{NaCl}, \mathrm{pH} 7.0$, at $37^{\circ} \mathrm{C}$ and the reaction was terminated by adding $0.2 \mathrm{~N} \mathrm{HCl}$. Color was developed by the addition of iodine solution $\left(0.02 \% \mathrm{I}_{2}, 0.2 \% \mathrm{KI}\right.$ solution), and the remaining starch was determined spectrophotometrically at $700 \mathrm{~nm}$. One unit of activity was determined as the amount of protein that hydrolyzes $1 \mathrm{mg}$ of starch in $1 \mathrm{~min}^{4)}$.

Fifty micro liter of the crude and purified enzyme $(0.007$ $\mathrm{mg} / \mathrm{ml}$ ) solution and $300 \mu \mathrm{l}$ of substrate (containing $0.2 \%$ starch and 4.3 M NaCl, pH 7.0) were mixed in a test tube with screw cap in the absence or presence of $100 \mu$ l of organic solvents ( $n$-decane: $\log P_{\text {ow }}=6.0, n$-nonane: $5.5, n$-octane: 4.5 , cyclohexane: 3.4 , xylene: 3.1 , styrene: 2.9 , toluene: 2.8 , benzene: 2.1 and chloroform: 1.9). $\log P_{\mathrm{ow}}$ (common 
logarithm of the partition coefficient of a given solvent in a mixture of $n$-octanol and water) is an index of biological toxicity ${ }^{5)}$. Lower values represent higher toxicity. It was then incubated at $37^{\circ} \mathrm{C}$ for $1 \mathrm{hr}$, and activity was estimated by measuring OD $700 \mathrm{~nm}$. Optimal temperature of this amylase was $50^{\circ} \mathrm{C}$, but organic solvent is easy to disappear at high temperature. So, in this study, effect of organic solvent on activity and stability was confirmed at $37^{\circ} \mathrm{C}$. Inhibitory effects of each organic solvent were less than $20 \%$ in the crude or purified enzyme. One hundred percent activity remained in the absence of organic solvents. Crude or purified enzyme activity did not almost change in the presence of organic solvents.

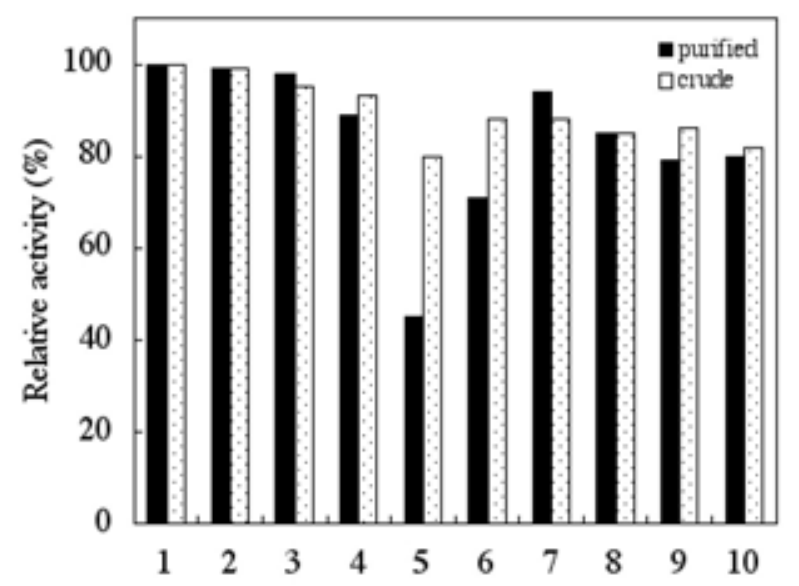

Fig. 1. Effect of organic solvents on enzyme stability. Amylase was incubated for $1 \mathrm{hr}$ in buffer containing $4.3 \mathrm{M} \mathrm{NaCl}$ in the presence of organic solvents. The remaining activity was measured in buffer containing $0.2 \%$ starch. 1 : without solvents 2: $n$-decane ( $\left.\log P_{\mathrm{ow}}=6.0\right), 3: n$-nonane (5.5), $4: n$-octane (4.9), 5: cyclohexane (3.4), 6: xylene (3.1), 7: styrene (2.9), 8: toluene (2.8), 9: benzene (2.1), and 10: chloroform (1.9).

To examine stability of the amylase to organic solvents, the crude or purified enzyme was incubated in $50 \mathrm{mM}$ tris- $\mathrm{HCl}$ buffer ( $\mathrm{pH} 7.0$ ) containing $4.3 \mathrm{M} \mathrm{NaCl}$ with organic solvent for $1 \mathrm{hr}$ at $25^{\circ} \mathrm{C}$ and remaining activity was measured. In crude enzyme, more than $80 \%$ activity was observed in the presence of $n$-decane, $n$-nonane, $n$-octane, cyclohexane, xylene, styrene, toluene, benzene or chloroform. In purified enzyme, more than $70 \%$ activity was observed in the presence of such organic solvents, and $45 \%$ activity was detected in the presence of cyclohexane (Fig. 1). Stability of crude enzyme was higher than one of purified enzyme especially in the presence of cyclohexane or xylene. Impurity within crude enzyme may affect enzyme stability in the presence of organic solvents.

Time courses of the remaining activity were measured in the presence of various organic solvents. Two hundred micro liter of enzyme $(0.007 \mathrm{mg} / \mathrm{ml})$ solution and $200 \mu \mathrm{l}$ of organic solvents (styrene, toluene, benzene and chloroform: lower log
$P_{\text {ow }}$ value selected) were mixed in a $2.0 \mathrm{ml}$ micro centrifuge tubes with screw caps. It was then incubated at $25^{\circ} \mathrm{C}$ for 120 hr with vigorously shaking at 160 strokes per minute and measurement of remaining activity was performed. More than $78 \%$ remaining activity was determined after incubation at $25^{\circ} \mathrm{C}$ for $120 \mathrm{hr}$ in the presence of every solvent (Fig. 2). This enzyme is very stable in the presence of hydrophobic organic solvents.

On the other hand, activity was inhibited in the presence of hydrophilic organic solvents. Among them, no activity was detected in the presence of ethyl alcohol or acetone. Besides, ratio of reaction products was changed in the absence or presence of 20\% 2-propyl alcohol. Major products of $\alpha$-amylase from S-1 were glucose, maltose and maltotriose, and their ratios were $40 \%, 16 \%$ and $31 \%$, respectively in the absence of organic solvent. On the other hand, product ratios were $36 \%, 26 \%$ and $20 \%$ respectively in the presence of 2-propyl alcohol. In the case of enzyme-substrate complex of amylase reaction, water is used as an acceptor, and hydrolysis reaction proceeds. Besides, transfer reaction proceeds when enzyme-substrate complex uses alcohol as acceptor ${ }^{14)}$. Therefore, balance of hydrolysis reaction and transfer reaction of halophilic amylase might be changed in the presence of 2-proryl alcohol.

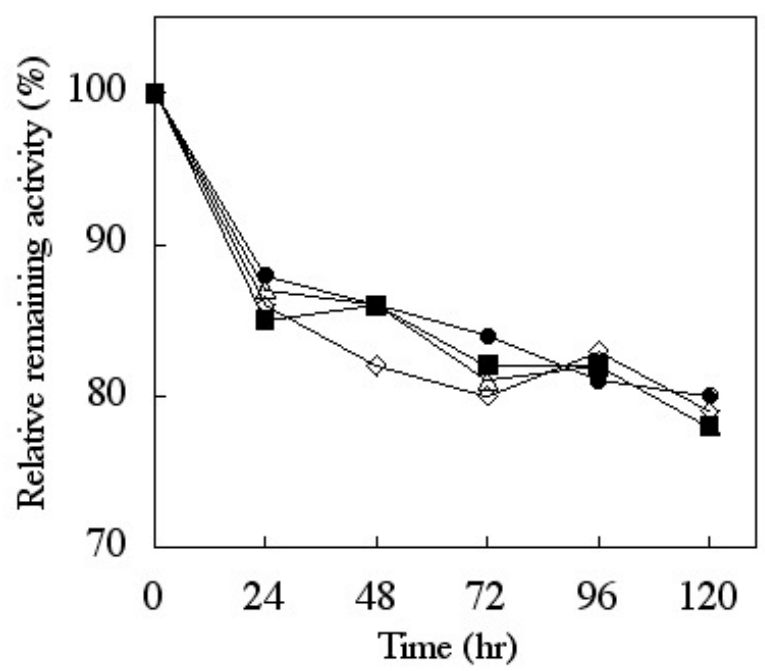

Fig. 2. Time courses of the remaining activity in the presence of various organic solvents. The enzyme was incubated at $25^{\circ} \mathrm{C}$ with shaking in the presence of organic solvents styrene, $\mathbf{\square}$ : toluene, $\diamond$ : benzene and $\triangle$ : chloroform).

Effect of organic solvent on activity and stability were tested at various temperatures. In this study, used organic solvent was chloroform. Chloroform was dropped down below the buffer and hard to disappeared in comparison with other solvents. Temperature dependency of halophilic $\alpha$-amylase was tested. Fifty micro liter of enzyme $(0.007 \mathrm{mg} / \mathrm{ml})$ solution 
and $300 \mu \mathrm{l}$ substrate containing $50 \mathrm{mM}$ tris- $\mathrm{HCl}$ buffer $(\mathrm{pH}$ 7.0) and $4.3 \mathrm{M} \mathrm{NaCl}$ were mixed into test tubes (screw capped) and incubated for $1 \mathrm{hr}$ at various temperatures in the absence or presence of chloroform. For each temperature, starch concentration was $0.2 \%$. Optimum temperature was $50^{\circ} \mathrm{C}$ with or without chloroform. Moreover, $27 \%$ and $73 \%$ activity were observed at $10^{\circ} \mathrm{C}$ and $70^{\circ} \mathrm{C}$, respectively, in the presence of chloroform. Besides, $13 \%$ and $62 \%$ activity were detected at $10^{\circ} \mathrm{C}$ and $70^{\circ} \mathrm{C}$, respectively, in the absence of chloroform (Fig. 3). One hundred percent activity remained with or without chloroform at $50^{\circ} \mathrm{C}$.

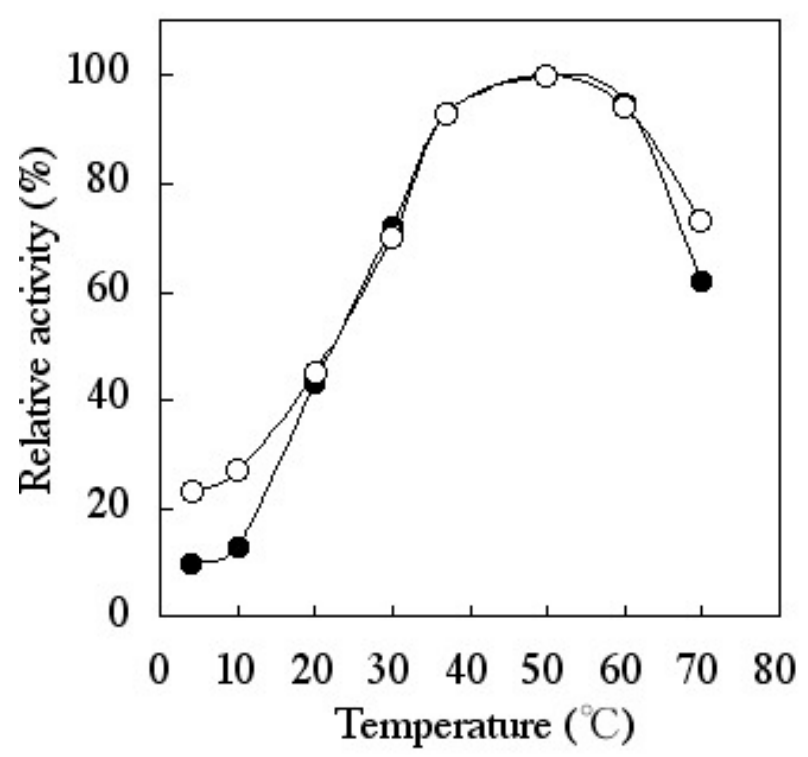

Fig. 3. Effect of chloroform on amylase activity at various temperatures. Enzyme sample and substrate were mixed into test tube (screw capped) and incubated for $1 \mathrm{hr}$ at various temperatures in the absence or presence of chloroform. without chloroform, $\bigcirc$ : with chloroform

Stability of halophilic $\alpha$-amylase at various temperatures was determined by incubating an enzyme $(0.007 \mathrm{mg} / \mathrm{ml})$ sample in $50 \mathrm{mM}$ tris- $\mathrm{HCl}(\mathrm{pH} 7.0)$ buffer containing $4.3 \mathrm{M}$ $\mathrm{NaCl}$ for $30 \mathrm{~min}$ at various temperatures in the absence or presence of chloroform, and the remaining activity was measured. As shown in Fig. 4, 50\% and 56\% activity was observed at $70^{\circ} \mathrm{C}$ in the absence or presence of chloroform, respectively.

This enzyme was comparatively stable at high temperature, and enzyme activity and stability with chloroform was higher than without chloroform at low or high temperature. As described above, chloroform may soften the effect of temperature on enzyme activity and stability.

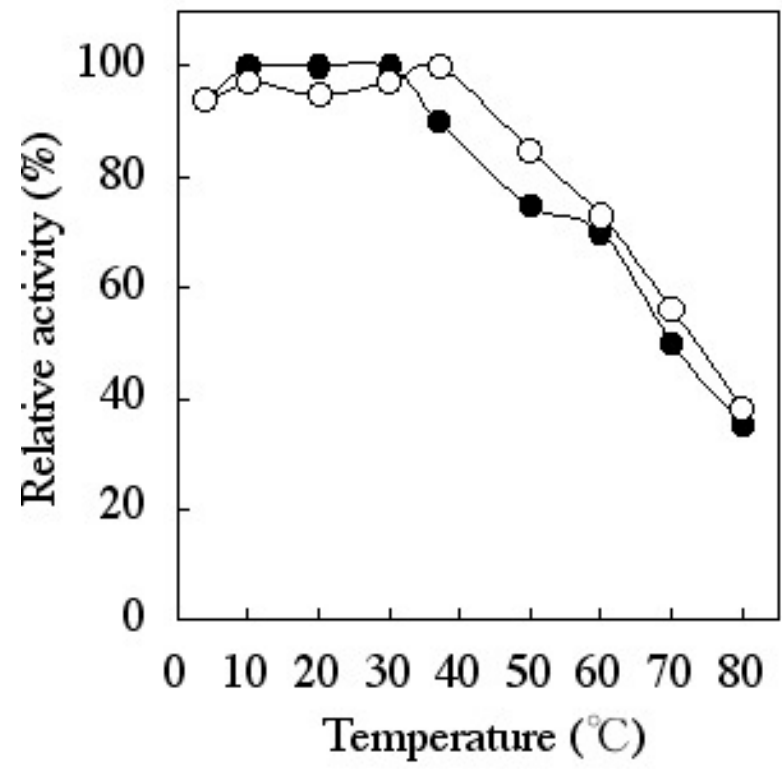

Fig. 4. Effects of chloroform on thermostability at various temperatures. For determining the thermostability, amylase was incubated at each temperature for $30 \mathrm{~min}$ and the remaining activity was measured. 0 : without chloroform, $\bigcirc$ : with chloroform

Effect of EDTA on activity in the presence or absence of chloroform was checked. Ten micro liter of EDTA solution and $300 \mu \mathrm{l}$ substrate containing $50 \mathrm{mM}$ tris- $\mathrm{HCl}$ buffer $(\mathrm{pH}$ 7.0), $0.2 \%$ starch and $4.3 \mathrm{M} \mathrm{NaCl}$ were mixed into test tubes with screw caps, and $50 \mu \mathrm{l}$ of enzyme $(0.007 \mathrm{mg} / \mathrm{ml})$ solution was added. Final EDTA concentration was changed from 5 to $15 \mathrm{mM}$. The solution was then incubated at $37^{\circ} \mathrm{C}$ for $1 \mathrm{hr}$ with or without chloroform. Amylase activity was inhibited in the presence of EDTA (5-15 mM) with or without chloroform. But, when EDTA (5-15 mM) was added, the enzyme activity was higher in the presence of chloroform than that without chloroform (Fig. 5).

Important metal ion for $\alpha$-amylase activity is calcium ion ${ }^{15)}$, and it is lost in the presence of EDTA. Chloroform may play a similar role as calcium ion lost by EDTA to stabilize the enzyme, or important metal ion for the activity may be difficult to be detached in the presence of chloroform.

Halophilic $\alpha$-amylase from strain S-1 was very stable in the presence of organic solvents. Activity and stability of this amylase with chloroform was higher than that without chloroform at the low or high temperature. The enzyme activity was higher in the presence of chloroform than one without chloroform when EDTA (5-15 mM) was added. These results were confirmed in the presence or absence of styrene, toluene, and benzene. Consequently, halophilic $\alpha$-amylase was could be used in industrial processes containing high salt concentration and organic solvents. In the future, we want to 
perform gene cloning and expression of the enzyme in E. coli or Haloferax volcanii ${ }^{8}$.

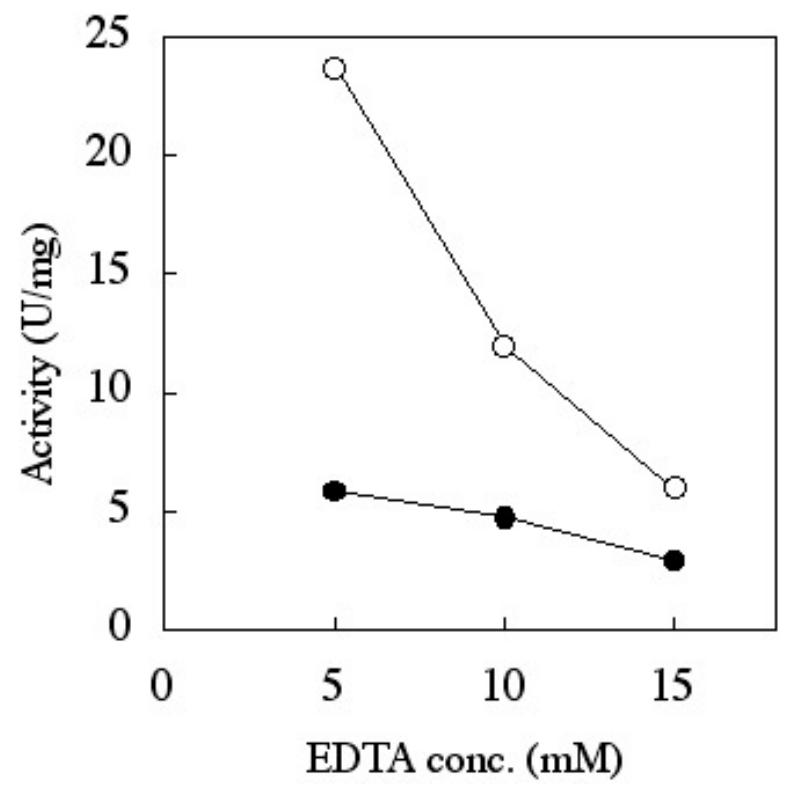

Fig. 5. Effect of EDTA on amylase activity in the absence or presence of chloroform. Amylase activity was measured after incubation at $37^{\circ} \mathrm{C}$ for $1 \mathrm{hr}$ in buffers containing EDTA (5-15 $\mathrm{mM}), 0.2 \%$ starch, and $4.3 \mathrm{M} \mathrm{NaCl}$ in the absence () or presence $(\bigcirc)$ of chloroform.

\section{Acknowledgements}

Part of this study has been supported by a grant for the 21 st Century's Center of Excellence Programs organized by the Ministry of Education, Culture, Sports, Science and Technology, Japan, since 2003.

\section{References}

1) Danson, M.J., and Hough, D.W. 1997. The structural basis of halophilicity. Comp. Biochem. Physiol. 3: 307-312.

2) Dym, O., Mevarech, M., and Sussman, J.L. 1995. Structural features that stabilize halophilic malate dehydrogenase from archaebacterium. Science 267: 1344-1346.

3) Fukushima, T., Mizuki, T., Echigo, A., Inoue, A., and Usami, R. Organic solvent tolerance of halophilic $\alpha$-amylase from a Haloarchaeon, Haloarcula sp. Strain S-1. 2005 Extremophiles 9: 85-89.

4) Haseltine, C., Rolfsmeier, M., Blum, P. 1996. The glucose effect and regulation of the $\alpha$-amylase synthesis in the hyperthermophilic archaeon Sulfolobus solfataricus. J. Bacteriol. 4: 945-950.
5) Inoue, A., and Horikoshi, K. 1991. Estimation of solvent-tolerance of bacteria by solvent parameter log P. J. Ferment. Bioeng. 71: 194-196.

6) Kadziola, A., Søgaard, M., and Svensson, B. 1998. Molecular structure of a barley $\alpha$-amylase-inhibitor complex: implications for starch binding and catalysis. J. Mol. Biol. 278: 205-217.

7) Kanai, H., Kobayashi, T., Aono, R., and Kudo, T. 1995. Natronococcus amylolyticus sp. nov., a haloalkaliphilic archaeon. Int. J. Syst. Bacteriol. 45: 762-766.

8) Kobayashi, K., Kanai, H., Aono, R., Horikoshi, K., and Kudo, T. 1994. Cloning, expression, and nucleotide sequence of the $\alpha$-amylase gene from the haloalkaliphilic archaeon Natronococcus sp. strain Ah-36. J. Bacteriol. 176: 5131-5134.

9) Kobayashi, K., Kanai, H., Hayashi, T., Akiba, T., Akaboshi, R., and Horikoshi, K. 1992. Haloalkaliphilic maltotriose-forming $\alpha$-amylase from the archaebacterium Natronococcus sp. strain Ah-36. J. Bacteriol. 174: 3439-3444.

10) Machius, M., Wiegand, G., and Huber, R. 1995. Crystal structure of calcium depleted Bacillus lincheniformis $\alpha$-amylase at 2.2 A resolution. J. Mol. Biol. 246: 545-559.

11) Marhuenda-Egea, F.C., and Bonete, M.J. 2002. Extreme halophilic enzymes in organic solvents. Curr. Opin. Biotechnol. 13: 385-389.

12) Perez-Pomares, F., Bautista, V., Ferrer, J., Pire, C., Marhuenda-Egea, F.C., and Bonete, M.J. 2003. $\alpha$-Amylase activity from the halophilic archaeon Haloferax mediterranei. Extremophiles 7: 299-306.

13) Rodriguez-Valera, F., Juez, G., and Kushner, D.J. 1983. Halobacterium mediterranei sp. nov., a new carbohydrate-utilizing extreme halophile. Syst. Appl. Microbiol. 4: 369-387.

14) Sawai, T., and Hehre, E.J. 1962. A novel amylase (Candida transglucosyl-amylase) that catalyzed glucosyl transfer from starch and dextrins. J. Biol. Chem. 237: 2047-2052.

15) Vallee, B.L., Stein, E.A., Sumerwell, W.N., and Fischer, E.H. 1959. Metal content of $\alpha$-amylase of various origins. J. Biol. Chem. 234: 2901-2905.

16) Vihinen, M., and Mäntsälä, P. 1989. Microbial amylolytic enzymes. Crit. Rev. Biochem. Mol. Biol. 24: 329-418. 